\title{
Konsensusbaserte retningslinjer kan hindre nødvendig forskning
}

\author{
Konsensusbaserte retningslinjer fra ekspertgrupper kan ha mangelfull vitenskapelig dokumentasjon. \\ Om ikke mangelen poengteres, kan slike retningslinjer tildekke behov og hindre nødvendige videre studier. \\ Et eksempel på dette er den langvarige diskusjonen om fjerning av kolorektale polypper.
}

Vi trenger kliniske retningslinjer utarbeidet av eksperter som har gått igjennom all vitenskapelig dokumentasjon på området. Retningslinjer bør være basert på den beste tilgjengelige vitenskapelige dokumentasjonen, f.eks. flere uavhengige randomiserte studier, såkalt evidensgrad A (1-3). Etterspørselen etter retningslinjer er imidlertid størst når kunnskapsgrunnlaget er svakt. Da baserer man seg gjerne på «konsensus blant eksperter» og ikke vitenskapelig kunnskapsgrunnlag (evidensgrad D, laveste rangerte evidensnivå). Når konsensusbaserte retningslinjer får fotfeste $\mathrm{og}$ danner grunnlaget for alminnelig klinisk praksis, risikerer man en overskygging av behovet for supplerende studier - noen studier kan endog bli betraktet som uetiske å utføre. Det hviler derfor et stort ansvar på «eksperter» som vanligvis oppnevnes til konsensusgruppene, ikke minst en klar selvinnsikt i den begrensede overføringsverdien av egne kasuistikkbaserte erfaringer. Konsensusbaserte retningslinjer sier sjelden noe om hvilken supplerende forskning det er viktig å utføre, eller på hvilke områder kunnskapsgrunnlaget er for dårlig til å kunne gi anbefalinger.

\section{Adenomer i tykktarm - hva skal gjøres?}

I en nylig artikkel i BMJ tar vi opp denne problemstillingen i forbindelse med behandling og oppfølging av pasienter med kolorektale polypper (4). Artikkelen viser til at konsensusbaserte retningslinjer fra 1980-årene anbefalte svært hyppige kontroller etter fjerning av kolorektale adenomer. Anbefalingene er gradvis modifisert i senere retningslinjer, og nå anbefales det kontrollkoloskopi hvert tredje, femte eller tiende år, eller ikke i det hele tatt (3). På epidemiologisk grunnlag kan vi anta at mindre enn $5 \%$ av de kolorektale adenomene utvikler seg til kreft i løpet av et liv, men vi vet ikke hvilke dette er. $95 \%$ av polyppektomiene er således egentlig unødvendige, men risikoen ved denne overbehandlingen er vanligvis liten en metaanalyse har vist $0,1 \%$ perforasjonsrisiko ved terapeutiske koloskopier (dvs. med polyppektomi) (5). Mer enn 120 år etter de første publikasjonene om det som senere ble betegnet som adenom-karsinom-sekvensteorien kjenner vi fortsatt ikke alle detaljer i den naturlige utviklingen av adenomer (6). Konsensusbaserte retningslinjer gjorde det vanskelig å utføre randomiserte studier på in situ-adenomer i 1980-årene.

\section{Nye polypper - gamle feil}

Inntil nylig har adenomer vært betraktet som den eneste polypptypen med potensial til å utvikle seg til kolorektal kreft. Nå er det funnet molekylære fellestrekk med kolorektal kreft $\mathrm{i}$ en type polypper som betegnes som sessile serraterte polypper (serratert $=$ sagtakket relieff ved mikroskopi) (4). Tidligere ignorerte vi disse som ufarlige hyperplastiske polypper, og vi vet veldig lite om hvilken fare de egentlig representerer. I en studie var assosiasjonen mellom kolorektal kreft og serraterte polypper $\geq 10 \mathrm{~mm}$ ikke mye høyere enn assosiasjonen mellom kolorektal kreft og alder $\geq 65$ år (justert oddsratio på henholdsvis $3,34 \mathrm{og} 2,63$ ) (7).

Serraterte polypper er spesielt tillagt en rolle ved utvikling av proksimalt lokalisert kolorektal kreft (8). I motsetning til adenomer, som ofte er stilkede og lokalisert i distale colon og rectum der tarmveggen er tykkere, er serraterte polypper vanligvis bredbasede (sessile) og lokalisert i den tynnveggede proksimale colon. Dette gir en vesentlig høyere risiko for perforasjon ved polyppektomi, uten at vi vet hvor stor nytten er. Ved screening med sigmoidoskopi eller koloskopi er deteksjon og fjerning av polypper sentralt for å redusere forekomst og dødelighet av kolorektal kreft (4). Motivasjonen for å fjerne polypper hos friske screeningdeltakere er derfor sterk. Polyppforekomsten blant screeningdeltakere er vesentlig høyere enn livstidsrisikoen for kolorektal kreft (4). Nytte-risiko-forholdet ved polyppfjerning må derfor kunne dokumenteres med stor sikkerhet. Heller enn ukritisk å følge konsensusbaserte retningslinjer bør man i screeningprogrammer ta ansvar for nødvendig kunnskapsutvikling. Ved å fungere som en plattform for sammenliknende forskning på effekt (comparative effectiveness research) kan screeningprogrammer tilføre betydelig kunnskap med overføringsverdi til klinisk arbeid. Konsensusbaserte retningslinjer har i over 30 år gitt betydelig overbehandling av kolorektale adenomer uten å ha økt kunnskapen om det naturlige forløpet av kolorektale adenomer. Nå er historien i ferd med å gjenta seg med ny (begrenset) kunnskap om serraterte polypper, men med vesentlig større risiko for komplikasjoner enn ved polyppektomi av adenomer. Generelt er det behov for å etterspørre kvaliteten på dokumentasjon for gjeldende praksis innenfor mange fagområder av medisinen. Det kan være nyttig å stadig spørre seg hva man driver på med, hva slags nytte det har og til hvilken pris (risiko).

\section{Geir Hoff \\ hofg@online.no \\ Michael Bretthauer \\ Kjetil Garborg \\ Tor Jac Eide}

Geir Hoff (f. 1946) er spesialist i fordøyelsessykdommer, med spesialkompetanse innen kolorektalcancerscreening og kvalitetssikringsarbeid. Han er assisterende forskningssje ved Sykehuset Telemark, professor II ved Universitetet i Oslo og rådgiver ved Kreftregisteret. Han er leder for det nasjonale kvalitetsregisteret Gastronet.

Forfatter har fylt ut ICMJE-skjemaet og oppgir ingen interessekonflikter.

Michael Bretthauer (f. 1969) er spesialist i indremedisin, professor ved Avdeling for helseledelse og helseøkonomi, Universitetet i Oslo og overlege ved Seksjon for fordøyelsessykdommer, Avdeling for transplantasjonsmedisin, Oslo universitetssykehus.

Forfatter har fylt ut ICMJE-skjemaet og oppgir følgende interessekonflikter: Han har mottatt styrehonorar fra Exact Sciences, ekspertvitnehonorar fra Norchip/Hjort advokater og utstyr til endoskopiforskning fra Olympus, Fujinon, CCS og Falk Pharma.

Kjetil Garborg (f. 1976) er lege i spesialisering i fordøyelsessykdommer ved Sørlandet Sykehus, Kristiansand og ph.d.-stipendiat ved Det medisinske fakultet, Universitetet i Oslo. Forfatter har fylt ut ICMJE-skjemaet og oppgir ingen interessekonflikter.

Tor Jac Eide (f.1946) er spesialist i patologi, med spesialkompetanse i fordøyelsesorganenes patologi. Han er fungerende avdelingsleder ved Avdeling for patologi, Oslo universitetssykehus og professor ved Universitetet i Oslo. Forfatter har fylt ut ICMJE-skjemaet og oppgir ingen interessekonflikter. 
Litteratur

1. Baker A, Young K, Potter J et al. A review of grading systems for evidence-based guidelines produced by medical specialties. Clin Med 2010; 10 358-63.

2. Schünemann HJ, Fretheim $A, O x m a n A D$ et al. Research WHOACOH. Improving the use of research evidence in guideline development: 1 . Guidelines for guidelines. Health Res Policy Syst 2006; 4: 13.

3. Vonen BGM, Edna TH, Rørum LMR et al. Nasjonalt handlingsprogram med retningslinjer for diagnostikk, behandling og oppfølging av tykk- og endetarmskreft. Oslo: Helsedirektoratet, 2013.

4. Hoff G, Bretthauer M, Garborg K et al. New polyps, old tricks: controversy about removing benign bowel lesions. BMJ 2013; 347: f5843.

5. Panteris V, Haringsma J, Kuipers EJ. Colonoscopy perforation rate, mechanisms and outcome: from diagnostic to therapeutic colonoscopy. Endoscopy 2009; 41: 941-51.

6. Esmarch F. Die Krankheiten des Mastdarmes und des Afters. Deutsche Chirurgie 48. Stuttgart: F. Enke, 1887

7. Hiraoka S, Kato J, Fujiki S et al. The presence of large serrated polyps increases risk for colorectal cancer. Gastroenterology 2010; 139: 1503-10, e1-3.

8. Rex DK, Ahnen DJ, Baron JA et al. Serrated lesions of the colorectum: review and recommendations from an expert panel. Am J Gastroenterol 2012; 107: 1315-29, quiz 1314, 1330.

Mottatt 11.10. 2013, første revisjon innsendt 30.10. 2013, godkjent 16.12. 2013. Redaktør: Are Brean.

Publisert først på nett. 